\title{
HUBUNGAN KEBIASAAN MEROKOK DAN KONSUMSI KAFEIN DENGAN KEJADIAN OSTEOPOROSIS PADA USIA LANJUT
}

\author{
Dwi Nonita Nugraheni ${ }^{1}$, Sri Wahyu Basuki ${ }^{2}$, Anika Candrasari ${ }^{2}$, Budi Hernawan ${ }^{2}$ \\ ${ }^{1}$ Mahasiswa Fakultas Kedokteran, Universitas Muhammadiyah Surakarta \\ ${ }^{2}$ Dosen Fakultas Kedokteran, Universitas Muhammadiyah Surakarta
}

\begin{abstract}
Korespondensi:
Dwi Nonita Nugraheni

Email author:

j500170046@student.ums.ac.id
\end{abstract}

Riwayat Artike

Diterima: 21 Maret 2021

Selesai revisi: 5 Juli 2021

DOI :

10.53366/jimki.v9i1.368

\section{ABSTRAK}

Pendahuluan: Osteoporosis merupakan penyakit gangguan metabolik pada tulang yang ditandai dengan penurunan massa tulang, sehingga tulang menjadi rapuh dan mudah patah. Kebiasaan merokok menjadi faktor risiko terjadinya osteoporosis, karena pada perokok akan kehilangan massa tulang lebih cepat dibandingkan bukan perokok. Asupan kafein berlebih dikaitkan dengan efek negatif kafein pada homeostasis tulang. Penelitian ini bertujuan untuk menganalisis hubungan kebiasaan merokok dan konsumsi kafein dengan kejadian osteoporosis pada usia lanjut.

Metode: Desain penelitian ini adalah studi literatur atau literature review. Penelitian ini mengambil sumber dari Pubmed, Science Direct, dan Google Scholar dengan kata kunci: (smoking OR smoking habits) AND (caffeine OR caffeine consumption OR drink coffee) AND (osteoporosis) AND (elderly OR aged). Hasil pencarian didapatkan 1.136 artikel, dan setelah duplikat dihilangkan tersisa 1.104 artikel. Selanjutnya, diidentifikasi berdasarkan judul, abstrak, dan kelayakan yang sesuai dengan kriteria restriksi, didapatkan 8 artikel yang direview.

Pembahasan: Hasil penelitian dari artikel menyatakan bahwa merokok dapat meningkatkan risiko osteoporosis. Konsumsi kafein tinggi berisiko osteoporosis, sedangkan konsumsi kafein rendah hingga sedang dapat menurunkan risiko osteoporosis.

Simpulan: Berdasarkan hasil penelitian yang telah dilakukan dapat disimpulkan bahwa terdapat hubungan yang signifikan antara kebiasaan merokok dan mengkonsusmsi tinggi kafein terhadap risiko osteoporosis pada usia lanjut.

Kata Kunci: Kafein, Kebiasaan merokok, Lansia, Osteoporosis 


\title{
RELATIONSHIP OF SMOKING HABITS AND CONSUMING CAFFEINE WITH OSTEOPOROSIS EVENTS IN ADVANCED AGE
}

\begin{abstract}
Background: Osteoporosis is a disease of metabolic disorders in the bones characterized by a decrease in bone mass, so that bones become brittle and break easily. Smoking habits a risk factor for osteoporosis, because smokers lose bone mass faster than nonsmokers. Excessive caffeine intake is associated with the negative effect of caffeine on bone homeostasis. The purpose of this study was to analyze the relationship between smoking and caffeine consumption and the incidence of osteoporosis in the elderly.

Methods: The design of this research is a literature study or literature review. This study draws sources from Pubmed, Science Direct, and Google Scholar with the keywords: (smoking OR smoking habits) AND (caffeine OR caffeine consumption OR drink coffee) AND (osteoporosis) AND (elderly OR aged). The search results found 1,136 articles, and after the duplicates were removed 1,104 articles were left. Furthermore, identified based on the title, abstract, and eligibility in accordance with the restriction criteria, 8 articles were reviewed.

Discussion: The research results from the article stated that smoking can increase the risk of osteoporosis. High caffeine consumption is at risk of osteoporosis, while low to moderate caffeine consumption can reduce the risk of osteoporosis.

Conclusion: Based on the results of the research that has been done, it can be concluded that there is a significant relationship between smoking habits and high consumption of caffeine on the risk of osteoporosis in the elderly.
\end{abstract}

Keywords: Caffeine, Smoking habits, Elderly, Osteoporosis

\section{PENDAHULUAN}

Osteoporosis

dini. ${ }^{1}$ WHO menyebutkan secara

osteoporosis menduduki peringkat

kedua setelah penyakit kardiovaskular sebagai masalah kesehatan global. ${ }^{2} \mathrm{Di}$ seluruh dunia jumlah penderita osteoporosis mencapai 200 juta penduduk dan di Amerika Serikat 1,5 juta kasus patah tulang terjadi setiap tahunnya. $^{3}$ WHO melaporkan bahwa penduduk dunia usia $\geq 50$ tahun paling banyak mengalami fraktur osteoporosis terjadi di Eropa yaitu sebesar 34,8\% dan Asia Tenggara menempati urutan ketiga dengan jumlah 17,4\%. ${ }^{4}$ Perhimpunan Osteoporosis Indonesia melaporkan bahwa prevalensi osteoporosis di Indonesia usia di atas 50 tahun pada wanita sebesar $32,3 \%$, sedangkan pada pria sebesar $28,8 \% .^{5}$

$$
\text { Kejadian osteoporosis }
$$

meningkat seiring bertambahnya populasi usia lanjut. ${ }^{6}$ Sebesar $19,7 \%$ dari jumlah lansia atau sekitar 3,6 juta orang di Indonesia menderita osteoporosis, sementara itu di Yogyakarta terdapat $23,5 \%$ lansia mengalami osteoporosis. ${ }^{7}$ Penelitian Afni \& Hanafi (2019), menunjukkan bahwa lansia berusia $>65$ tahun 9 kali lebih berisiko mengalami osteoporosis dibandingkan lansia usia $\leq 65$ tahun dan perempuan memiliki risiko 4 kali lebih besar mengalami osteoporosis dibandingkan laki-laki. ${ }^{8}$

Osteoporosis pada lansia dapat terjadi karena beberapa faktor, seperti ras atau genetik, jenis kelamin, penurunan hormon, postur tubuh kecil, kurang aktivitas fisik, kebiasaan merokok, kurang paparan sinar matahari, asupan kalsium rendah, konsumsi kafein dan alkohol, minuman bersoda, konsumsi obat-obatan jangka panjang, dan diabetes mellitus. ${ }^{9}$

Peningkatan proporsi merokok pada masyarakat setiap hari dari tahun 2007-2013 sebesar 23,7\% - 24,3\%. Peningkatan konsumsi rokok berpengaruh terhadap tingginya beban penyakit akibat rokok dan bertambahnya angka kematian. ${ }^{10}$ Menurut WHO, 
kebiasaan merokok menjadi faktor risiko terjadinya osteoporosis karena pada perokok akan kehilangan massa tulang lebih cepat dibandingkan bukan perokok. ${ }^{11}$ Berdasarkan penelitian Suarni (2017), diketahui bahwa merokok menyebabkan terjadinya osteoporosis pada lansia sebesar $40 \%$. Penelitian Dimyati (2017), dengan uji chi-square didapatkan $\mathrm{p}=0,047 \quad(\mathrm{p}<0,05) \quad$ yang berarti terdapat hubungan signifikan antara kebiasaan merokok dengan kejadian osteoporosis dan hasil perhitungan OR didapatkan 3,121 $(1,133<\mathrm{OR}<8,603)$ berarti kebiasaan merokok berat pada lansia memiliki peluang 3,121 kali untuk terjadi osteoporosis dibandingkan dengan kebiasaan merokok ringan. ${ }^{12}$

Asupan kafein berlebih dikaitkan dengan efek kafein pada homeostasis tulang. Kafein dapat meningkatkan ekskresi kalsium sehingga berpotensi terjadinya osteoporosis. ${ }^{13}$ Pusat Data dan Sistem Informasi Pertanian (2016) menyebutkan rata-rata pertumbuhan konsumsi kopi di Indonesia dari tahun 2016-2020 sebesar 2,49\% dan diperkirakan akan terus meningkat setiap tahunnya. ${ }^{14}$ Penelitian Kiaonarni et al. (2012) menyatakan bahwa faktor terjadinya osteoporosis pada wanita lansia akibat pecandu kopi sebesar $29 \% .{ }^{15}$ Penelitian Parinduri et al. (2017), dengan uji chi-square didapatkan $p=0,028 \quad(p<0,05) \quad$ berarti terdapat hubungan yang signifikan antara konsumsi kafein dengan kepadatan tulang. ${ }^{16}$

Penelitian Juniarsana \& Wiardani (2012) dengan uji statistik menyebutkan tidak ada hubungan yang signifikan antara kebiasaan merokok dan minum kopi pada lansia terhadap risiko osteoporosis $(p>0,05)$. Penelitian Verinda \& Herwana (2020), dengan uji Fisher menyatakan tidak terdapat hubungan yang bermakna antara asupan kafein total dengan kepadatan tulang $(p=0,419)$ dan dengan uji chisquare juga tidak didapatkan hubungan yang bermakna $(p=0,728 ; p>0,05)$.

Berdasarkan uraian di atas dan beberapa penelitian yang sudah dilakukan masih terdapat pro dan kontra, maka dari itu penulis tertarik untuk melakukan analisis studi literatur review tentang hubungan kebiasaan merokok dan konsumsi kafein dengan kejadian osteoporosis pada usia lanjut.

\section{METODE}

Penelitian ini menggunakan desain penelitian Literatur Review. Studi literatur review merupakan penelitian kepustakaan dengan membaca berbagai buku, artikel, dan terbitanterbitan yang berkaitan dengan suatu topik penelitian untuk menghasilkan tulisan berkaitan dengan topik tersebut. ${ }^{17}$

Penelitian dilakukan dengan melakukan pencarian di internet. Database yang digunakan meliputi Pubmed, Science Direct, dan Google Scholar dengan kata kunci: (smoking OR smoking habits) AND (caffeine OR caffeine consumption $O R$ drink coffee) AND (osteoporosis) AND (elderly OR aged).

Analisis data dilakukan dengan menggunakan narrative review, yaitu dengan mengelompokkan data hasil skrining sesuai dengan kriteria inklusi, kemudian dijadikan dalam bentuk tabel yang meliputi nama dan tahun terbit artikel, subjek penelitian, judul penelitian, metode penelitian, dan ringkasan hasil penelitian. Selanjutnya, data dilakukan pembahasan dan kesimpulan.

\section{HASIL PENELITIAN}

Proses pemilihan artikel dilakukan dengan metode PRISMA (Preferred Reporting Items for Systematic Reviews and MetaAnalyses) yang terdiri dari beberapa langkah yaitu identifikasi, skrining, uji kelayakan, dan inklusi. Total pencarian yang didapatkan dari database Pubmed, Science Direct, dan Google Scholar sebanyak 1.136 artikel, lalu setelah duplikat dihilangkan tersisa 1.104 artikel. Kemudian diidentifikasi berdasarkan judul, abstrak, dan kelayakan yang sesuai dengan kriteria restrisksi, didapatkan 8 artikel yang direview. 
Tabel 1. Analisa Narrative

\begin{tabular}{|c|c|c|c|c|}
\hline $\begin{array}{c}\text { Author, } \\
\text { Tahun } \\
\text { Peneliti } \\
\text { an }\end{array}$ & $\begin{array}{c}\text { Subjek } \\
\text { Penelitian }\end{array}$ & Judul & $\begin{array}{l}\text { Metode } \\
\text { Penelitian }\end{array}$ & Hasil \\
\hline $\begin{array}{l}\text { Trevisan } \\
\text { et al., } \\
2019\end{array}$ & $\begin{array}{l}1.067 \text { wanita } \\
\text { pascamenopaus } \\
\text { e }\end{array}$ & $\begin{array}{l}\text { The Impact of } \\
\text { Smoking on } \\
\text { Bone } \\
\text { Metabolism, } \\
\text { Bone Mineral } \\
\text { Density and } \\
\text { Vertebral } \\
\text { Fractures in } \\
\text { Postmenopausa } \\
\text { I Women }\end{array}$ & $\begin{array}{l}\text { Cross- } \\
\text { sectional - } \\
\text { prospective } \\
\text { study }\end{array}$ & $\begin{array}{l}\text { Mengalami patah } \\
\text { tulang belakang } \\
\text { meningkat } 74 \% \\
\text { (interval kepercayaan } \\
95 \%: 1,07-2,83 \text { ) } \\
\text { dibandingkan dengan } \\
\text { yang tidak pernah } \\
\text { merokok. }\end{array}$ \\
\hline $\begin{array}{l}\text { Marque } \\
\text { s et al., } \\
2018\end{array}$ & $\begin{array}{l}2.673 \text { orang } \\
\text { dewasa tua } \\
\text { (55,9\% wanita), } \\
\text { berusia } 66-92 \\
\text { tahun }\end{array}$ & $\begin{array}{l}\text { Cigarette } \\
\text { smoking and hip } \\
\text { volumetric bone } \\
\text { mineral density } \\
\text { and cortical } \\
\text { volume loss in } \\
\text { older adults: } \\
\text { The AGES- } \\
\text { Reykjavik study }\end{array}$ & $\begin{array}{l}\text { Reykjavik } \\
\text { study }\end{array}$ & $\begin{array}{l}\text { Perokok saat ini } \\
\text { memiliki kehilangan } \\
\text { vBMD trabekuler, } \\
\text { vBMD integral, yang } \\
\text { lebih besar secara } \\
\text { signifikan } \\
\text { dibandingkan dengan } \\
\text { perokok yang tidak } \\
\text { pernah merokok. }\end{array}$ \\
\hline $\begin{array}{l}\text { Yang et } \\
\text { al., } 2015\end{array}$ & $\begin{array}{l}1.817 \text { peserta } \\
\text { usia } 30-90 \text { tahun }\end{array}$ & $\begin{array}{l}\text { Associations } \\
\text { between } \\
\text { frequency of } \\
\text { coffee } \\
\text { consumption } \\
\text { and } \\
\text { osteoporosis in } \\
\text { Chinese } \\
\text { postmenopausa } \\
\text { I women }\end{array}$ & $\begin{array}{l}\text { Cross- } \\
\text { sectional } \\
\text { study }\end{array}$ & $\begin{array}{l}\text { Frekuensi asupan kopi } \\
\text { sedang secara } \\
\text { independen dan } \\
\text { signifikan terkait } \\
\text { dengan osteoporosis } \\
(p<0,001) \text {. }\end{array}$ \\
\hline $\begin{array}{l}\text { H. C. } \\
\text { Chang } \\
\text { et al., } \\
2018\end{array}$ & $\begin{array}{l}2.682 \text { peserta } \\
\text { terdiri dari } 1.195 \\
\text { laki-laki dan } \\
1.487 \\
\text { perempuan }(706 \\
\text { premenopause } \\
\text { dan } 781 \\
\text { pascamenopaus } \\
\text { e) }\end{array}$ & $\begin{array}{l}\text { Does coffee } \\
\text { drinking have } \\
\text { beneficial } \\
\text { effects on bone } \\
\text { health of } \\
\text { Taiwanese } \\
\text { adults? A } \\
\text { longitudinal } \\
\text { study }\end{array}$ & $\begin{array}{l}\text { Longitudina } \\
\text { I study }\end{array}$ & $\begin{array}{l}\text { Minum kopi sedang } \\
\text { dan tinggi dikaitkan } \\
\text { dengan } T \text {-score yang } \\
\text { lebih tinggi, hasil } \\
\text { signifikan pada } \\
\text { peminum tinggi } \\
\text { ( } \beta=0,158 ; P=0,0038) \text {, } \\
\text { uji tren linier } \\
(P=0,0046) \text {. Pria } \\
\text { peminum kopi tinggi } \\
\text { hasil signifikan } \\
(\beta=0,237 ; P=0,0067) \text {, } \\
\text { uji tren ( } P=0,0161) \text {. } \\
\text { Wanita } \\
\text { pascamenopause hasi } \\
\text { signifikan untuk minum } \\
\text { kopi tinggi }(\beta=0,233 ; \\
P=0,0355) \text { dan minum }\end{array}$ \\
\hline
\end{tabular}




\begin{tabular}{|c|c|c|c|c|}
\hline & & & & $\begin{array}{l}\text { kopi sedang }(\beta=0,234 ; \\
P=0,0152) \text {, uji tren } \\
\text { linier }(P=0,0108) \text {. }\end{array}$ \\
\hline $\begin{array}{l}\text { Choi et } \\
\text { al., } 2016\end{array}$ & $\begin{array}{l}4.066 \text { wanita } \\
\text { pascamenopaus } \\
\text { e (usia rata-rata } \\
62,6 \text { tahun) }\end{array}$ & $\begin{array}{l}\text { The Benefit of } \\
\text { Bone Health by } \\
\text { Drinking Coffee } \\
\text { among Korean } \\
\text { Postmenopausa } \\
\text { I Women: A } \\
\text { Cross-Sectional } \\
\text { Analysis of the } \\
\text { Fourth \& Fifth } \\
\text { Korea National } \\
\text { Health and } \\
\text { Nutrition } \\
\text { Examination } \\
\text { Surveys }\end{array}$ & $\begin{array}{l}\text { Cross- } \\
\text { sectional } \\
\text { study }\end{array}$ & $\begin{array}{l}\text { BMD meningkat } \\
\text { dengan asupan kopi } \\
\text { yang lebih tinggi dari } \\
\text { leher femoralis }(P \text { tren } \\
=0,019) \text { dan tulang } \\
\text { belakang lumbal ( } P \\
\text { tren }=0,051) .\end{array}$ \\
\hline $\begin{array}{l}\text { Yu et } \\
\text { al., } 2016\end{array}$ & $\begin{array}{l}\text { Lebih dari } 3.000 \\
\text { peserta (laki-laki } \\
\text { dan wanita) usia } \\
30-90 \text { tahun }\end{array}$ & $\begin{array}{l}\text { Subjective } \\
\text { evaluation of } \\
\text { the frequency of } \\
\text { coffee intake } \\
\text { and relationship } \\
\text { to osteoporosis } \\
\text { in Chinese men }\end{array}$ & $\begin{array}{l}\text { Cross- } \\
\text { sectional } \\
\text { study }\end{array}$ & $\begin{array}{l}\text { Korelasi positif antara } \\
\text { frekuensi asupan kopi } \\
\text { dan } T \text {-score }(\beta=0,211 \\
P=0,024)\end{array}$ \\
\hline $\begin{array}{l}\text { Zhaoli } \\
\text { Dai et } \\
\text { al., } 2018\end{array}$ & $\begin{array}{l}63.257 \text { populasi } \\
\text { dengan pria } \\
(\mathrm{n}=27.959) \text { dan } \\
\text { wanita } \\
(\mathrm{n}=35.298), \\
\text { berusia } 45-74 \\
\text { tahun }\end{array}$ & $\begin{array}{l}\text { Coffee and tea } \\
\text { drinking in } \\
\text { relation to risk } \\
\text { of hip fracture in } \\
\text { the Singapore } \\
\text { Chinese Health } \\
\text { Study }\end{array}$ & $\begin{array}{l}\text { Cohort- } \\
\text { prospective } \\
\text { study }\end{array}$ & $\begin{array}{l}\text { Peminum kopi } \geq 4 \\
\text { cangkir/hari, memiliki } \\
\text { risiko tinggi lebih } \\
\text { signifikan untuk terjadi } \\
\text { patah tulang pinggul } \\
\text { (95\% Cl) [HR: } 1,32 \\
(1,07,1,63)] \text { di seluruh } \\
\text { analisis kelompok, } \\
\text { [HR: } 1,46(1,01,2,10)] \\
\text { untuk pria dan }[\mathrm{HR}: \\
1,33(1,02,1,72)] \\
\text { untuk wanita. Di antara } \\
\text { wanita menopause } \\
\text { yang minum } 2-3 \\
\text { cangkir/hari dikaitkan } \\
\text { dengan risiko rendah } \\
\text { [HR: } 0,88(0,76,1,01)] \\
\text { dan minum } \geq 4 \\
\text { cangkir/hari dikaitkan } \\
\text { dengan risiko tinggi } \\
\text { [HR: } 1,31(1,00,1,71)] \text {. }\end{array}$ \\
\hline $\begin{array}{l}\text { Ugurlu } \\
\text { et al., } \\
2015\end{array}$ & $\begin{array}{l}175 \text { wanita } \\
\text { pascamenopaus } \\
\text { e diatas } 35 \\
\text { tahun }\end{array}$ & $\begin{array}{l}\text { Assessment of } \\
\text { smoking for low } \\
\text { bone mineral } \\
\text { density in } \\
\text { postmenopausa } \\
\text { I Turkish women }\end{array}$ & $\begin{array}{l}\text { Statistical } \\
\text { Package }\end{array}$ & $\begin{array}{l}\text { Hasil } T \text {-score femur }(- \\
0,78 \pm 1,07 \text { vs. }-0,32 \pm \\
1,56) \text { dan } T \text {-score } \\
\text { vertebra }(-2,26 \pm 1,23 \\
\text { vs. }-1,82 \pm 1,04) \\
\text { secara signifikan lebih } \\
\text { rendah pada wanita } \\
\text { perokok dibandingkan } \\
\text { wanita yang tidak }\end{array}$ \\
\hline
\end{tabular}


\begin{tabular}{l|l}
\hline & \\
4. PEMBAHASAN & \\
Osteoporosis merupakan \\
kelainan pada tulang yang ditandai
\end{tabular} dengan berkurangnya massa tulang dan kerusakan mikroarsitektur jaringan tulang yang menyakibatkan peningkatan kerapuhan dan terjadi patah tulang. ${ }^{18}$

Pengukuran BMD (Bone Mineral Density) digunakan dalam mendiagnosis osteoporosis. Menurut WHO, seseorang didiagnosis osteoporosis apabila pada pemeriksaan BMD nilai dari $T$-score menunjukkan hasil $\leq-2,5 .{ }^{19}$ Faktor gaya hidup seperti merokok berakibat buruk terhadap rendahnya kepadatan mineral tulang (BMD) ${ }^{20}$ Hubungan merokok dan BMD telah dijelaskan dalam penelitianpenelitian sebelumnya. Penelitian Marques et al. (2018) mencatat bahwa merokok berkaitan dengan vBMD yang lebih rendah. Merokok juga berdampak terhadap $T$-score, dalam penelitian Ugurlu et al. (2015) menunjukkan bahwa merokok berdampak pada penurunan $T$ score femur dan vertebra daripada wanita bukan perokok. ${ }^{21}$

Salah satu faktor risiko osteoporosis yang dapat dimodifikasi yaitu merokok, dimana ini merupakan faktor risiko paling berpengaruh terhadap kesehatan tulang. Merokok dapat memberikan dampak negatif pada kesehatan tulang dengan mekanisme ganda. Pertama, yaitu dengan memberikan efek toksik langsung pada osteoblas dan aliran darah yang akan mempengaruhi kesehatan tulang dan menyebabkan risiko patah tulang terutama tulang femur. Kedua, yaitu berkaitan dengan efek tidak langsung pada tulang yang dapat mempengaruhi hormon seks sehingga dapat menghambat aksis vitamin D-PTH pada wanita pascamenopause, dimana vitamin D-PTH berperan dalam pengaturan homeostasis kalsium dan fosfat. Pada perokok menunjukkan nilai PTH rata-rata lebih rendah daripada mantan perokok dan orang yang tidak pernah merokok. Penelitian Trevisan et al. (2019) menyebutkan bahwa merokok memiliki efek negatif terhadap kepadatan mineral tulang wanita pascamenopause sehingga berisiko mengalami patah tulang belakang. ${ }^{22}$ merokok $(p<0,05)$.

Konsumsi kopi dikaitkan dengan peningkatan faktor risiko patah tulang osteoporosis. Kopi mengandung senyawa yang kompleks termasuk kafein di dalamnya.

Frekuensi konsumsi kopi penting untuk menentukan hubungan konsumsi kopi dan kesehatan tulang. Beberapa penelitian menyebutkan bahwa konsumsi kopi berlebih dikaitkan dengan risiko osteoporosis. ${ }^{23}$ Asupan kafein tinggi terbukti menghambat pembentukan tulang dan menurunkan kepadatan mineral tulang. Penelitian Zhaoli Dai et al. (2018) menyebutkan bahwa asupan tinggi kafein dapat meningkatkan risiko patah tulang pinggul pada pria dan wanita, sedangkan asupan kafein sedang dapat menurunkan risiko terhadap osteoporosis pada wanita pascamenopause. ${ }^{24}$ Penelitian Yang et al. (2015) menunjukkan bahwa frekuensi asupan kopi berhubungan secara independen dan signifikan terhadap osteoporosis. Asupan kopi dalam jumlah tinggi akan meningkatkan ekskresi kalsium dalam urin, sedangkan asupan kopi dalam jumlah sedang berisiko lebih rendah terhadap osteoporosis dan bermanfaat dalam pencegahan osteoporosis.

Mekanisme manfaat kopi bagi kesehatan tulang masih belum jelas diketahui. Penelitian H. C. Chang et al. (2018) yang pertama menunjukkan efek perlindungan dari minum kopi dengan risiko osteoporosis pada wanita pascamenopause. Minum kopi secara bermakna dihubungkan dengan $T$-score yang lebih tinggi, dimana peningkatan massa tulang dapat berfungsi sebagai pencegahan terhadap pengeroposan tulang. Penelitian Choi et al. (2016) menyatakan bahwa konsumsi kopi meningkat diikuti peningkatan BMD leher femur dan tulang belakang. ${ }^{25}$

\section{SIMPULAN}

1. Terdapat hubungan yang signifikan antara kebiasaan merokok terhadap risiko osteoporosis pada usia lanjut.

2. Terdapat hubungan yang signifikan antara mengkonsumsi tinggi kafein terhadap risiko osteoporosis pada usia lanjut. 


\section{SARAN}

Perlu dilakukan penelitian lebih lanjut mengenai berbagai faktor risiko lain penyebab osteoporosis dan manfaat kopi terhadap kesehatan tulang.

\section{DAFTAR PUSTAKA}

1. Yusni Y, Rahman S. Kebiasaan konsumsi kopi teratur dan pengaruhnya terhadap resorpsi tulang: C-telopeptida dan kalsium serum pada olahragawan. J Gizi Indones (The Indones $J$ Nutr. 2019;7(2):92-98.

doi:10.14710/jgi.7.2.92-98

2. Sani N, Yuniastini $Y$, Putra A, Yuliyana Y. Tingkat Pengetahuan Osteoporosis Sekunder dan Perilaku Pencegahan Mahasiswa Universitas Malahayati. J IIm Kesehat Sandi Husada. 2020;11(1):159-163.

doi:10.35816/jiskh.v11i1.236

3. Cheraghi P, Cheraghi Z, Bozorgmehr S. The Prevalence and risk factors of osteoporosis among the elderly in Hamadan province: A cross sectional study. Med J Islam Repub Iran. 2018;2018:648-652.

doi:10.14196/mjiri.32.111

4. Pradipta DR, Dieny FF. Asupan Protein Yang Kurang Sebagai Faktor Risiko Kepadatan Tulang Rendah Pada Wanita Pascamenopause. J Nutr Coll. 2014;3(4):620-630.

doi:10.14710/jnc.v3i4.6861

5. Luthfie NAM, Herwana E. Asupan isoflavon yang tinggi meningkatkan kepadatan tulang pada perempuan pascamenopause. J Biomedika dan Kesehat. 2019;2(4):132-137. doi:10.18051/jbiomedkes.2019.v2 .132-137

6. Suarni L. SOSIAL LANJUT USIA DI WILAYAH BINJAI TAHUN 2017 Factors Causing Osteoporosis Disease on Elderly in Service Age Social UPT in Binjai Region 2017 Dosen Akademi Keperawatan Sehat
Binjai. $J$ Ris Hesti Medan. 2017;2(1):60-65.

7. Soke YE, Judha M, Amestiasih T. Hubungan Pengetahuan Lansia Tentang Osteoporosis Dengan Perilaku Mengkonsumsi Makanan Berkalsium Di Panti Wredha $X$ Yogyakarta. J Keperawatan Respati. 2016;3(1):66-71.

8. Afni R, Hanafi A. Risiko Osteoporosis pada Lansia Di UPT Panti Sosial Tresna Werdha Khusnul Khotimah Pekanbaru. Risiko Osteoporos Pada Lansia Di Upt Panti Sos Tresna Werdha Khusnul Khotimah Pekanbaru. 2019;3(1):16-21.

9. Hidayah N, Kholidah D, Mustafa A. Edukasi Gizi Dengan Media Booklet Terhadap Tingkat Pengetahuan, Asupan Kalsium Dan Aktivitas Fisik Untuk Mencegah Osteoporosis Pada Lansia. J Pendidik Kesehat. 2019;8(1):79-92.

10. Kemenkes. Perilaku Merokok Masyarakat Indonesia. Published online 2014:1-11.

11. Juniarsana IW, Wiardani dan NK. Hubungan Kebiasaan Minum Kopi Dan Merokok Terhadap Kejadian Osteoporosis Pada Lansia Di Denpasar. J IImu Gizi. 2012;3(1):38-44.

12. Dimyati KF. Correlations Between Physical Activity, Smoking Habit And Attitude In Elderly With Incidence of Osteoporosis. J Berk Epidemiol. 2017:5(1):107. doi:10.20473/jbe.v5i12017.107-

117

13. Verinda S, Herwana E. Asupan kafein dari kopi dan teh serta hubungannya dengan kepadatan tulang pada perempuan pascamenopause. J Biomedika dan Kesehat. 2020;3(2):70-76. doi:10.18051/jbiomedkes.2020.v3 .70-76

14. Pusat Data dan Sistem Informasi Pertanian KP. Outlook Kopi Komoditas Pertanian Subsektor Perkebunan. Pus Data Dan Sist Inf Pertan Sekr Jenderal. Published online 2016:116. http://perpustakaan.bappenas.go.i d/lontar/opac/themes/bappenas4/t emplateDetail.jsp?id=167009\&lok 
asi=lokal

15. Kiaonarni OW, Adin M, S EN, Eko a C, Irine C. Faktor Penyebab Terjadinya Osteoporosis Pada Wanita Lansia. J Keperawatan. 2012;5(3):131-134.

16. Parinduri FK, Rahfiludin $M Z, P$ SF. Hubungan Asupan Kalsium, Vitamin D, Fosfor, Kafein, Aktivitas Fisik Dengan Kepadatan Tulang Pada Wanita Dewasa Muda (Studi Kasus Pada Mahasiswi S1 Reguler Fakultas Kesehatan Masyarakat Universitas Diponegoro Angkatan 2014). J Kesehat Masy. 2017;5(4):664-674.

17. Marzali A. ETNOSIA. J Etnogr Indones. 2016;1(2):27-36.

18. Chang HC, Hsieh CF, Lin YC, et al. Does coffee drinking have beneficial effects on bone health of Taiwanese adults? A longitudinal study. BMC Public Health. 2018;18(1):1-10. doi:10.1186/s12889-018-6168-0

19. Setyohadi B, Hutagalung EU, Adam JMF, et al. Summary of Indonesian Guidelines for Diagnosis and Management of Osteoporosis. J ASEAN Fed Endocr Soc. 2012;27(2):147-150. doi:10.15605/jafes.027.02.02

20. Ugurlu U, Nayki U, Nayki C, Ulug $P$, Kulhan $M$, Yildirim $Y$. Assessment of smoking for low bone mineral density in postmenopausal Turkish women. Wien Klin Wochenschr. 2015;128(3-4):114-119.

doi:10.1007/s00508-015-0867-7

21. Marques EA, Elbejjani $M$, Gudnason V, et al. Cigarette smoking and hip volumetric bone mineral density and cortical volume loss in older adults: The AGES-Reykjavik study. Bone. 2018;108:186-192.

doi:10.1016/j.bone.2018.01.014

22. Trevisan C, Alessi A, Girotti G, et al. The Impact of Smoking on Bone Metabolism, Bone Mineral Density and Vertebral Fractures in Postmenopausal Women. J Clin Densitom. 2019;23(3):1-9. doi:10.1016/j.jocd.2019.07.007

23. Yang $P$, Zhang $X Z$, Zhang $K$, Tang Z. Associations between frequency of coffee consumption and osteoporosis in Chinese postmenopausal women. Int $J$ Clin Exp Med. 2015;8(9):1595815966.

24. Zhaoli Dai, Jin A, Soh AZ, Ang LW, Yuan J-M, Koh W-P. Coffee and tea drinking in relation to risk of hip fracture in the Singapore Chinese Health Study. HHS Public Access. 2018;176(10):117.

doi:10.1016/j.bone.2018.04.010.C offee

25. Choi E, Choi KH, Park SM, Shin $D$, Joh HK, Cho E. The benefit of bone health by drinking coffee among Korean postmenopausal women: A cross-sectional analysis of the fourth \& fifth Korea National Health and Nutrition Examination Surveys. PLoS One. 2016;11(1):1-14.

doi:10.1371/journal.pone.0147762 